\title{
Reinventing the third mission of higher education in Germany: political frameworks and universities' reactions
}

\author{
Hendrik Berghaeuser $^{1} \cdot$ Michael Hoelscher $^{2}$ D
}

Received: 15 November 2018 / Accepted: 23 April 2019/Published online: 23 May 2019

(C) The Author(s) 2019

\begin{abstract}
Higher education systems are changing due to trends of funding pressures, increasing social demands and growing numbers of students. Even though teaching and research are still considered as the pivotal functions of universities, other activities such as technology transfer, lifelong learning or social engagement have broadened the scope of their actions. These activities, labelled as third mission, are supposed to strengthen the impact of science in society and epitomize the changing role of universities. In Germany, the federal government and the states announced different programs aiming to foster these activities, e.g. the "Innovative Hochschule" or Real-world Laboratories. In this article, we first want to develop a definition framework of third mission. In two further steps we analyze how politics and policies in Germany have framed the concept in the last few years and how public universities are responding to this in their formal structure. We use approaches of neo-institutional theory according to which organizations such as universities create institutionalized structures and reflect institutional rules in order to maintain legitimacy. As an example of organizational formal structure we analyze mission statements of public universities. Using computerbased qualitative content analysis, we assess to what extent these universities take up the third mission. Our results show that most universities mention the third mission in their mission statements. However, the focus is mainly limited to economic impact and (technical) knowledge transfer. Much less emphasis is put on civic engagement or further education issues.
\end{abstract}

Keywords Highereducation·Neo-institutionalism·Thirdmission · Missionstatements · Germany

Michael Hoelscher

hoelscher@uni-speyer.de; https://www.uni-speyer.de/hoelscher

1 Fraunhofer Institute for Systems and Innovation Research, Breslauer Straße 48, 76139 Karlsruhe, Germany

2 German University of Administrative Sciences Speyer, Postfach 14 09, 67324 Speyer, Germany 


\section{Introduction}

The so-called third mission has gained much attention within higher education policy as well as in academic discourses during the last few years in Germany. With regard to research, for example, two large projects tried to develop an overarching common understanding of the concept (Pasternack et al. 2015; Henke et al. 2016a, b; Roessler et al. 2015; Hachmeister et al. 2016). In the political realm, different new funding schemes with a focus on third mission have been launched, the largest one called "Innovative HE", sometimes described as the new and third pillar of the German Excellence Strategy.

There are different reasons for this. The German higher education system has seen dramatic changes over the last two or three decades. As a result, the context and setup of certain activities summarized under the label of third mission are changing. In the last decade of the twentieth century, the German higher education system exhibited relatively low student ratios for a highly developed country and was regularly criticized for this by the OECD (Hoelscher 2016: 95 ff.). Within the last 10 years, however, the number of students has increased from 1.94 million to 2.84 million in 2017/18 (Statistisches Bundesamt 2018: 10). In relative terms the higher education system has also experienced a rapid growth. The student ratio, i.e. the share of first-year-students among the age-specific population, has increased from $37.1 \%$ in 2005 to $58.2 \%$ in 2015 (Hüther and Krücken 2018). This expansion from a (nearly) elite system towards universal access (Trow 1972) has been accompanied by rising absolute, though shrinking relative, public funds for higher education. These rising expenditures, along with an increased autonomy of institutions following from the politics of new managerialism, fostered claims for accountability. At the same time, the decreasing relative share of public funds (1985: 67\%, 2014: 49\%) pushed higher education institutions towards third party funding. The discourse of the knowledge economy (e.g. Powell and Snellman 2004; Weber and Duderstads 2006) emphasizes the important role for regional and national economic competitiveness in higher education. Following from this is a focus on impact and "value for money" from the state, the economy and within higher education institutions at the same time.

In this context of increased accountability and competition, the hypothesis of this article is not only that the third mission as such has gained importance, but especially those dimensions of it that are related to the economy. In what follows we will therefore address two research questions conceptually as well as empirically:

1. What political concepts shape the framework for the third mission of universities in Germany?

2. How do universities in Germany react to political demands and deal with the third mission?

\section{Conceptualizing the third mission in the German higher education context}

The third mission in higher education is a globally occurring phenomenon, but yet it is embedded locally and adapted according to the regional framework conditions. In this respect, there is no universal valid definition of a third mission. In addition, the definition of which activities of universities are counted as part of the third mission varies considerably from one 
university system to the next (Göransson et al. 2009). In their analysis of the changed innovation processes and the extended scope of tasks of universities, Etzkowitz and Leydesdorff (2000) first coined the term third mission. Yet, in the description of the changed role model of the modern university, the third mission was often reduced to the university's contribution to (regional) economic development. According to this narrow understanding, third mission is usually related to commercialization activities and cooperation with (local) industry partners (Markman et al. 2005; Shattock 2005). In Germany, the political debate on third mission usually focuses on knowledge and technology transfer (Göransson et al. 2009).

In more recent research on higher education, however, a broader understanding of third mission has increasingly gained ground that refers not only to the economic dimension of university engagement, but their social contribution. This includes all social, entrepreneurial and innovative activities that universities perform in addition to their teaching and research duties (Zomer and Benneworth 2011; Loi and Di Guardo 2015). Glaser et al. (2014) for example subsume under the third mission very broadly all activities in which universities interact with the external environment. In this context Perkman and Walsh (2008) distinguish between commercialization activities and academic engagement. While commercialization activities are clearly measurable and direct contributions of universities to economic and social development, academic engagement describes more general knowledge-based co-operations with non-academic actors and organisations. As a consequence, the third mission goes well beyond cooperation with companies, but also links the university to civil society in general. The reference to societal developmental interests is thus a necessary condition for the characterization of the university's third mission (Henke et al. 2016a).

Resulting from this description, the third mission in Germany and many other contexts is described as activities that take place in the context of teaching and research without being teaching and research alone (Pasternack et al. 2015). They are characterized in that they:

- go beyond the first two missions of universities (teaching and research);

- use resources linked to the core tasks of the university, such as knowledge, research results, technology, personnel (students and staff), infrastructure or financial funding;

- involve actors outside the academic-scientific sector; and

- relate to socio-economic developments (Pasternack et al. 2015; Henke et al. 2016a).

As a result, purely administrative or internal operational activities of universities that do not give any impulses to society do not belong to the third mission, as universities would carry out these activities even if they had no interest in their social environment. This definition also excludes, for example, pure presence effects of universities such as personnel expenses, income effects or construction activities, as they are only triggered by the mere existence of the universities and consequently only contribute to the passive, but not to the active shaping of the social environment.

According to Pasternack et al. and Henke et al. three main dimensions of universities' activities can be described as third mission, following from this definition: (1) knowledge and technology transfer, (2) further education and (3) social engagement.

Knowledge and technology transfer describes the planned transfer of scientific and technological knowledge between individuals and organizations for the purpose of innovation through various activities (Koschatzky 2002). Transfer does not describe a one-sided exchange from universities to social actors, but rather a mutual interaction from which both sides profit (Schmoch et al. 2000). It enables organisational and institutional interactions between 
universities, companies, public research institutions or government authorities (Bozeman 2000). As a consequence, knowledge and technology transfer is a conscious, active, planned, goal-oriented, time-limited, inter-organizational and benefit-related exchange process between universities and other actors (Kersting 2013). Overall, there is a multitude of different approaches that attempt to define and conceptualize knowledge and technology transfer and its various components. Bozeman for example distinguishes different forms and channels of transfer and describes a system consisting of transfer donors, transfer media, transfer objects, demand environment and transfer recipients (Bozeman 2000).

Knowledge and technology transfer can also be divided into formal and informal transaction activities. Activities like contract research or licensing agreements count as formal forms of transfer, while informal knowledge and technology transfer refers to non-institutionalized or even random-based personnel exchange, which focuses rather on the transfer of implicit knowledge that takes place primarily in personal activities such as informal meetings, conferences and networks. (Bercovitz and Feldman 2006; Glaser et al. 2014; Brown 2016). Abreu and Grinevich and Moore et al. distinguish between four groups of knowledge and technology transfer activities - problem-solving activities such as contract research or consultancy, personal activities such as conferences, community-based activities such as exhibitions or school projects and commercialization activities such as spin-offs (Abreu and Grinevich 2013; Moore et al. 2009). Henke et al. try to distinguish knowledge and technology transfer more clearly, both in terms of traditional tasks in teaching and research, but also from other facets of third mission such as further education and social education. Consequently, they further subsume knowledge and technology transfer as activities that focus on mutual knowledge creation, knowledge and technology communication, commercialization and personal transfer (Henke et al. 2016a, b).

Further education refers to the increased need for further scientific training, as highly qualified knowledge-based work is characterized by a high need for renewal due to the dynamics of knowledge development. Further education has a particular advantage in this respect, since it can react quickly and flexibly to rapidly changing quantitative and qualitative qualification needs of employees (Schaeper et al. 2006). Universities are thus also reacting to the associated concept of lifelong learning, which has become increasingly important in recent years (Schuetze 2005). Consequently, this does not only include forms of "organized learning". The concept of lifelong learning includes informal learning and is not limited to a specific period after completion of an initial phase of education. Rather it relies on horizontal and vertical permeability in a networked education system (Hanft and Brinkmann 2013). As a consequence, further education in the German context can be subdivided into advanced degree study programs, short-term certificate studies, and other educational offers including continuing education courses.

Regarding social engagement, the state, civil society, students and the university itself can benefit. They can position themselves as competent partners of society and strengthen new cooperations with other civil society organisations. From a neo-institutionalist perspective, universities also strengthen their own legitimacy in this way. They become more attractive for potential students through greater social visibility and can, if necessary, incorporate experiences from social commitment into teaching and research. Students, on the other hand, are given the opportunity to test the possibilities and limits of the applicability of their academic knowledge through social commitment. In addition, they gain additional qualifications and important experience that are essential for their personal development. With regard to the state, social commitment through universities can strengthen democracy and social cohesion. In 
addition, it can contribute to the development and expansion of a civil society. Finally, civil society institutions benefit from the social commitment of universities by experiencing improvements in local living and working conditions and being included in knowledgebased design processes (Berthold et al. 2011). We subsume all social and civil activities of universities as social engagement, including widening access to higher education for

Table 1 Dimensions of third mission activities

\begin{tabular}{|c|c|c|}
\hline Dimensions & Aspects of specific dimension & Example activities \\
\hline \multirow[t]{4}{*}{$\begin{array}{l}\text { Knowledge and } \\
\text { technology } \\
\text { transfer }\end{array}$} & $\begin{array}{l}\text { (i) Co-operative knowledge } \\
\text { creation }\end{array}$ & $\begin{array}{l}\text { - Research co-operation } \\
\text { - Strategic partnerships and networks } \\
\text { - Joint scientific quarters or laboratories } \\
\text { - Joint professorship }\end{array}$ \\
\hline & $\begin{array}{l}\text { (ii) Knowledge and technology } \\
\text { communication }\end{array}$ & $\begin{array}{l}\text { - Contract research } \\
\text { - Scientific consulting }\end{array}$ \\
\hline & $\begin{array}{l}\text { (iii) Knowledge and technology } \\
\text { commercialization }\end{array}$ & $\begin{array}{l}\text { - Spin-offs } \\
\text { - Patenting and licensing }\end{array}$ \\
\hline & (iv) Personal transfer & $\begin{array}{l}\text { - Internships } \\
\text { - Dual studies } \\
\text { - Cooperative career service } \\
\text { - Alumni networks } \\
\text { - Parallel employment within and outside } \\
\text { higher education institutions }\end{array}$ \\
\hline \multirow[t]{3}{*}{$\begin{array}{l}\text { Further } \\
\text { education }\end{array}$} & (i) Advanced study programs & $\begin{array}{l}\text { - Advanced degree studies for working } \\
\text { professionals (B.Sc. or M.Sc.) }\end{array}$ \\
\hline & (ii) Certificate studies & $\begin{array}{l}\text { - Short-term qualification offers for specific } \\
\text { professional groups }\end{array}$ \\
\hline & (iii) Informal education & $\begin{array}{l}\text { - Guest studies } \\
\text { - Open seminars or lecture (series) }\end{array}$ \\
\hline \multirow[t]{7}{*}{$\begin{array}{c}\text { Societal } \\
\text { engagement }\end{array}$} & (i) Widening participation & $\begin{array}{l}\text { - Expansion of open admission procedures } \\
\text { - Access to higher education for } \\
\text { underprivileged groups }\end{array}$ \\
\hline & $\begin{array}{l}\text { (ii) Citizen science and public } \\
\text { engagement }\end{array}$ & $\begin{array}{l}\text { - Integration of the public into the research } \\
\text { process }\end{array}$ \\
\hline & $\begin{array}{l}\text { (iii) Science literacy, science } \\
\text { education and open science }\end{array}$ & $\begin{array}{l}\text { - Popular scientific publication } \\
\text { - Laboratories for children and high school } \\
\text { students } \\
\text { - Science festivals / "nights of sciences" } \\
\text { - Open access, Open review, Open metrics, } \\
\text { Open access to software and research data }\end{array}$ \\
\hline & (iv) Service learning & $\begin{array}{l}\text { - Integration of service and outreach activities } \\
\text { into student curricula }\end{array}$ \\
\hline & $\begin{array}{l}\text { (v) Community outreach, } \\
\text { Community service }\end{array}$ & $\begin{array}{l}\text { - Provision of infrastructures (libraries etc.) } \\
\text { - Outreach activities by members of higher } \\
\text { education institutions }\end{array}$ \\
\hline & (vi) Civic engagement & $\begin{array}{l}\text { - Support activities at elections } \\
\text { - Participation in campaigning }\end{array}$ \\
\hline & (vii) Social entrepreneurship & $\begin{array}{l}\text { - Social Entrepreneurship as part of student } \\
\text { curriculum } \\
\text { - Social entrepreneurship by staff of higher } \\
\text { education institutions }\end{array}$ \\
\hline
\end{tabular}


underrepresented social groups, public engagement, science literacy, science education and open science, service learning, community outreach and service, civic engagement as well as social entrepreneurship. Table 1 presents the main dimensions, its subgroups and example activities of the third mission.

\section{Third mission in German higher education policy}

In Germany, the Basic Law (i.e. the German constitution) assigns legislative sovereignty in the higher education sector to the 16 federal states (Länder). The states exercise this legislative sovereignty mainly in the form of the university laws in which they define tasks and set framework conditions for the efficient control and management of universities. Consequently, each of the 16 federal states has its own university law. Since the federal government withdrew as the framework legislator for the higher education landscape in Germany in 2006, state legislators have made great use of their relatively new competences, in particular through passing numerous and fundamental amendments to these university laws since 1998 (Hüther 2010).

In a previous study, Berghäuser (2017) analyzed the role of third mission in all of the 16 individual state university laws in Germany and showed that knowledge and technology transfer as well as further education are not just marginal phenomena in higher education governance, but are instead established as core tasks and demands of universities. The significance of the third mission is also made clear by it not only being mentioned as a task of higher education institution in general, but also defined as a task in the job description of higher education institutions' personnel. Professors and lecturers are requested to engage in third mission activities besides their teaching and research duties. The third mission is regulated in great detail in many areas. Most university laws contain extensive regulations for example on the provision of various forms of further education, ranging from offering advanced study programs, certificate studies to informal study programs like guest studies. Regarding knowledge and technology transfer, the laws contain numerous calls for higher education institutions to cooperate with non-university partners like private companies, to support commercialization activities like spinning out companies based on research results, or to promote personal transfer for example through expanding alumni networks or internship programs (Berghäuser 2017). With regard to social engagement, detailed regulations can be found in particular on the subject of widening participation and - to a lesser degree - open access. Other aspects of social engagement are hardly mentioned in the task description of universities. As a consequence, knowledge and technology transfer, further education and widening participation can be seen as a central component on the government's external control of universities.

While a close co-operation with the societal context is a traditional trait of the German higher education system as a coordinated market economy (Hall and Soskice 2001; Hoelscher 2016), the reforms in higher education laws in the last 20 years have made this explicit. To support this new emphasis on the third mission, the federal government as well as various states have introduced new funding schemes to foster universities' third mission. Two are probably especially important, as they are extremely visible (the real-world labs in the state of Baden-Württemberg) and/or distribute many resources (the joint federal and state program "Innovative University").

The "real-world labs" initiative of Baden-Württemberg started in 2013 and funded 14 projects with 18 million Euros since 2015, which seems quite a small amount of money. However, the innovative approach to cross boundaries by: a) bringing together people from within and outside academia (mainly from civil society, but also the economy, politics and administration), b) transfer experimental designs into larger real-world settings, and c) by 
focusing on co-design of research questions and co-production of research results, found considerable resonance in the German political and scientific landscape and is now also being emulated by other states in Germany. This initiative has a strong focus on sustainability as it was pushed by the first state-government with a Prime Minister from the Green party.

The program "Innovative University" (Innovative Hochschule) started a few years later in 2017 , is jointly funded by the federal and all state governments and is distributing up to 550 million Euros over a 10-year period. It is sometimes labelled as the "small excellenceinitiative", as it addresses smaller universities and universities of applied sciences, which were not able to participate in the general excellence initiative. Its aim is to strengthen universities' role in the regional innovation system and the co-operation with "the economy and other societal partners". A preliminary analysis of partners of the 29 projects that are being funded in the first round (2018-2022), based on the program and institutions' websites, displays a predominance of partners from the economic sphere in many projects, with a focus on technology transfer. However, other topics such as education, health, integration and sustainability also play an important role.

The two innovative programs exhibit a diversified approach to universities' third mission by the governments in their tenders as well as by higher education institutions in their projects. However, the larger program in particular shows a clear emphasis on economic issues and questions of knowledge and technology transfer. This is in line with the overall perception in Germany of an increasing importance of economic influences in the scientific subsystem (e.g. Münch 2014).

\section{The neo-institutionalist approach: Political guidance and organizational reactions}

\section{Universities as "open systems”}

Institutionalist theory assumes organizational reality as an open system in order to adjust for environmental shocks. As a consequence, the managerial level should mediate the balance between different levels (internal "production" and external "institutional") to maintain flexibility (Thompson 1967).

According to Meyer and Rowan (1977) the core assumption within neo-institutional theory is that organizations are embedded in a broader social context. They are deeply bound to and dependent on this social context through the distribution of material resources and legitimacy (see also Krücken 2003). The government, for example, exerts influence on the organization through binding guidelines, rules and regulation (DiMaggio and Powell 1983). Many organizations therefore adopt ceremonially institutionalized structures, techniques and/or policies as powerful myths in order to demonstrate conformity with external pressures. The idea behind this is that these myths are enforced by important constituents, by public opinion, by social prestige or by laws. The view on organizations as open systems highlights the variability and complexity of the individual parts of the organization. Parts (e.g. faculties) are then viewed as capable of semi-autonomous action (Weick 1982; Orton and Weick 1990).

In order to protect the productive core, organizations decouple this formal structure from the de-facto activity structure, especially when institutional pressures exist or when institutional environments and tasks are in conflict with each other (Meyer and Rowan 1977; Boxenbaum and Jonsson 2008; Powell and Bromley 2013). Organizations are then characterized by loose coupling between organizational practice and formal structure, where the former is mainly 
determined by efficiency concerns and the latter results from institutional pressure (Boxenbaum and Jonsson 2008). As a consequence, organizations can gain legitimacy in the institutional environment without having to alter the organization's activity structure. However, loose coupling can also create problems for coordination and control (Weick 1982; Krücken 2003). In a study on technology transfer offices at German universities, Krücken describes these technology transfer offices as examples of 'formal structure', because they constitute organizational subunits that were mainly established to meet political expectations and to buffer the organization from external pressures. As they lacked the required support from all relevant actors, they can be seen as a display window towards the universities' political environment that does not alter the organization's activity structure in a significant way (Krücken 2003).

Applied to our context, (public) universities are heavily dependent on the state's government and receive public funding from state ministries. The government defines tasks and demands by university laws, institutional contracts and through individual performance agreements with universities (Henke et al. 2016b). Universities react strongly to the pressure exercised by the state (Hüther and Krücken 2018). As public organizations, German universities in particular are expected to adapt common and successful models of "good practice" (Ramirez and Christensen 2013). This also helps to understand why universities are organized in colleges, faculties and departments or why universities set up technology transfer offices (Krücken 2003; Musselin 2007). As a consequence universities build up formal structures in which they express their conformity with demands and expectations from the government. By doing this, universities try to appear rational and gain legitimacy (e.g. Phillips and Ochs 2003).

\section{Mission statements as formal structure elements}

Mission statements are an organizational instrument used to develop individual profiles and to reinforce the branding activities of universities. It is an instrument that universities have adopted from business in order to communicate position, future vision and organizational strategy. In recent years, mission statements have become a 'must have' and imperative for modern higher education governance (Kosmützky and Krücken 2015).

From a neo-institutionalist point of view, mission statements mainly have the function to formulate the values of the organization and to communicate them externally in order to gain legitimacy. With mission statements organizations can convince their external stakeholders to provide necessary resources (Sanchez and Heene 2004; Desmidt et al. 2011). By communicating mission statements, universities can illustrate their importance to the institutional environment, in particular to (state) funding agencies and legislators. Mission statements thus have a symbolic information function about the corporate identity of the organization (Kosmützky 2010; Hanft 2000).

With mission statements, organizations try to demonstrate their openness and responsiveness to the social expectations directed at them. They thus strengthen the organization's ability to survive (Selznick 1957; Blair-Loy et al. 2011). Mission statements may then be used as instruments of public relations and in order to improve the external image of the organization. Accordingly, they do not necessarily describe the real motives for action of the organization. Rather, they adhere to a format and vocabulary that is taken for granted and rational in the social environment of the organization (Delucchi 2000). Mission statements are then a reaction to external expectations of the organization's institutional environment. Consequently, they may not adequately express the special features of the organization and only serve to satisfy particular political interests (Mackay et al. 1995; Davies and Glaister 1996). 
Mission statements may also be seen as a symbolic relief technique that reduces the complexity of reorganization by relieving pressure from external critics (Kehm and Pasternack 2001). Thus, mission statements give universities the opportunity to interpret social expectations and adapt them efficiently to the public. With the means of mission statements, universities attempt to tie the university closely to society and its needs. They hope for new resources, the acquisition of thirdparty funding and increased social legitimacy (Blair-Loy et al. 2011).

While the external function of mission statements is obvious, they are often rather weak and ineffective instruments for internal management, as it hardly influences the behavior or the sense of belonging of the members of the organization (Mackay et al. 1995; Stearns and Borna 1998). As a consequence, the self-descriptions of universities and the actual structures of the organization may diverge. Mission statements are thus a good example of the formal structure of universities that may have little to do with the actual activity structure of the organization (Meyer 2002; Kosmützky and Krücken 2015). According to this view, publishing mission statements is only a window-dressing reaction from universities (Jungblut and Jungblut 2017).

At the same time, however, mission statements also offer organizations the opportunity to communicate their own positions and values to the outside world. Thus, they can form a kind of strategic counterbalance to the institutional environment of the organization (Selznick 1948; Blair-Loy et al. 2011). Consequently, they are not only an expression of the reaction to external demands, but also a symbol of the increased institutional autonomy of universities. According to Meier (2009), the independent setting of organizational goals beyond external requirements symbolizes the claim to institutional autonomy. As a result, mission statements are also a proof that higher education institutions are pursuing a path of organizational self-management. In this view, mission statements describe the purpose of the organization and create unity within. They communicate the aims of the organization to its members as well as to its environment (James and Huisman 2009).

Whether as a reaction to external demands or as an expression of institutional autonomy, university mission statements address a host of external stakeholder groups such as research ministries, additional funding bodies, potential students and researchers, customer of research services, cooperation partners, accreditation authorities, etc. In this respect, the external communication function is a central goal and the marketing strategy is an important element of the mission statement concept. As heterogeneous organizations such as universities have diverse and many decentralized external relations, mission statements are an important element of the communication strategy of the overall organization and are therefore well suited for the analysis of organizational formal structures.

\section{Methodological approach}

\section{Data and sample description}

Due to the size and heterogeneity of the German higher education sector, it was necessary to limit the scope of the study. At the same time, there are still major differences in the national higher education system, especially with regard to the internal structures and duties of higher education institutions, although political reforms in recent years have attempted to soften these structural distinctions. In particular, the areas of responsibility of professors and scientific staff at universities of applied sciences ("Fachhochschulen"), such as teaching duties, still differ significantly from the conditions for teaching and research activities at (public) universities. 
Regarding the third mission, the bi-polarity in the German higher education system becomes even more obvious. While universities are entrusted with teaching and (basic) research, universities of applied sciences are assigned to carry out application-oriented teaching, applied research and development, as well as to engage closely with the (regional) economy. Most universities of applied sciences specialize in certain disciplines such as engineering or social work. Other disciplines such as medicine, humanities, natural sciences or law are usually not offered at this type of higher education institution (Hüther and Krücken 2018). Parts of the third mission are thus already defined in the function description of universities of applied science (Henke et al. 2016a). In order to achieve greater homogeneity, this analysis therefore only examines public state-funded universities.

According to the German higher education information platform Hochschulkompass there are currently (in 2018) 396 higher education institutions in Germany. 216 of them are public or private universities of applied science. Seven public universities focus on teacher education only (pedagogical universities), 57 universities are schools for music and arts, 13 universities are run by churches, and there are 21 private universities and 7 universities with a highly specified focus or special tasks such as the University for the Armed Forces, the University for Administrative Sciences, the University for Veterinary Medicine or the universities for the science of sport. All of these universities were excluded from the sample. As a consequence, the gross sample of this study is based on 75 public universities with a broad disciplinary spectrum; 17 of these universities are technical universities (see Table 2).

We searched for the mission statements of these 75 universities through internet research. The definition of mission statements used in this work is quite broad. Also, the term "mission statement" (Leitbild) cannot be found in many self-descriptions of universities. However, it is used here as a collective term for all forms of self-description. Consequently, all forms of published organizational self-description of the universities were taken into account, since the terms used by the universities for self-description were not uniform. The universities usually publish terms such as "mission statements", "guidelines", "vision(s)", "mission(s)", "(short) profiles", "guiding principles", etc. in synonymous form. As a consequence, we are using a broad definition of mission statements to increase the number of cases.

Overall, all but 2 of the 75 universities had published a mission statement, a profile or a similar form of self-description. This article therefore refers to 73 published mission statements of public universities in Germany. In some cases, mission statements were not published on websites, but could be found in annual reports or in goal and performance agreements between the organization and the responsible (state) ministry for research.

Table 2 Distribution of types of higher education institutions in the German higher education system

\section{Higher education institutes in Germany}

-216 Public or private universities of applied sciences

-57 Public or private universities for arts and music

-7 Pedagogical and dual universities

$=116$ Comprehensive universities

-21 Private universities

-13 Ecclesiastical universities (run by church)

$-7 \quad$ Public universities with specific disciplinary focus (Universities of the armed forces / Universities for the Science of Sport, University for Administrative Sciences, distance learning university, University for (veterinary) medicine

$\underline{\mathbf{7 5}}$ Public comprehensive universities 


\section{Qualitative content analysis}

Central to qualitative content analysis is the definition and application of a category system (Mayring 2015). Categories are descriptive analytical grids and are therefore more abstract than the material they are supposed to classify through generic terms. That means that categories must be precisely defined and logically delimited from each other (Lissmann 1997). We developed a category system that entails the three central dimensions of the third mission - knowledge and technology transfer, further education and social engagement. In order to gain a complete overview of the topic spectrum published in the mission statements, we also included categories that have no or only an indirect relation to the third mission. Besides the third mission, 13 further topics were identified in the mission statements and added to the category system.

The categories were developed through both an inductive approach - derived directly from the material to be investigated, without referring to previously formulated theoretical concepts - and deductively, based on prior theoretical knowledge or derived from formulated research interests or hypotheses. Table 3 summarizes the category systems with its 27 topical categories. We coded the mission statements based on the category system. The coding unit is the smallest possible text unit with content that is to be evaluated (Gläser-Zikuda 2008). Each code was then assigned to the (sub)categories. For data processing, we used MAXQDA software for qualitative analysis. The codings were then analyzed qualitatively and quantitatively.

\section{Results}

In the 73 examined mission statements we identified and coded 1989 content references. The data basis was very heterogeneous, in particular with regard to the scope and design of the university mission statements. By far the most extensive mission statement (Saarland University) contains 4026 words, almost twice as many as the second longest mission statement. The shortest self-description (University of Düsseldorf), on the other hand, contains only 104 words. On average, the university statements were 824 words long. Accordingly, the distribution of the codes is diverse, too. While we identified 120 content references in the mission statement of the Saarland University, only four contents were coded in the mission statement of the Hamburg City University as well as in the mission statement of the University of Paderborn. In addition, with 37 references, the mission statement of the Saarland University also has the most references to the third mission. Overall, we found 383 references to the third mission in the university mission statements. Table 4 shows detailed information about the descriptive statistics of the content analysis of the 73 university mission statements.

A general societal reference is used in almost 9 out of 10 university mission statements. Consequently, almost every mission statement combines the university's self-description with the aspiration to develop solutions for social challenges and problems. One example of this general societal reference is a description within the mission statement of the University of Lübeck:

In our knowledge society, science shapes all areas of social and private life. Science is the basis for personal, political and economic decisions. This gives science a great social responsibility, which the University of Lübeck accepts. (Mission Statement of the University of Lübeck, text segment 13, translated by author) 
Table 3 Category system for the analysis of university mission statements (own research)

\begin{tabular}{|c|c|}
\hline Main category & Sub-categories \\
\hline \multicolumn{2}{|l|}{ General societal reference } \\
\hline \multirow{4}{*}{$\begin{array}{l}\text { Knowledge and technology } \\
\text { transfer }\end{array}$} & Knowledge and technology transfer in general terms \\
\hline & $\begin{array}{l}\text { Cooperation with non-scientific partners (from industry, politics, culture } \\
\text { etc.) }\end{array}$ \\
\hline & Knowledge and technology commercialization (spin-offs, licensing etc.) \\
\hline & Personal transfer (alumni networks, internships, dual study programs etc.) \\
\hline \multirow[t]{4}{*}{ Further education } & Further education in general terms \\
\hline & Advanced study programs / Certificate studies \\
\hline & Guest studies \\
\hline & Cooperation with other further education actors \\
\hline \multirow[t]{6}{*}{ Social engagement } & Social engagement in general terms \\
\hline & Civic engagement \\
\hline & Community outreach / Community service / Service learning \\
\hline & Social entrepreneurship \\
\hline & Widening participation \\
\hline & Open science / Science literacy / Science education \\
\hline \multicolumn{2}{|c|}{ Cooperation with other scientific partners } \\
\hline \multicolumn{2}{|l|}{ Reference to region or city } \\
\hline \multicolumn{2}{|l|}{ Reference to history or legacy } \\
\hline \multicolumn{2}{|l|}{ International networks } \\
\hline \multicolumn{2}{|c|}{ (Ethnic) diversity and cosmopolitanism } \\
\hline \multicolumn{2}{|c|}{ Gender equality } \\
\hline \multicolumn{2}{|c|}{ Inter- and transdisciplinary science } \\
\hline \multicolumn{2}{|c|}{ Promotion of young academics } \\
\hline \multicolumn{2}{|l|}{ Sustainability } \\
\hline \multicolumn{2}{|c|}{ Excellence in research and teaching } \\
\hline \multicolumn{2}{|l|}{ Service orientation } \\
\hline \multicolumn{2}{|c|}{ Innovativeness in research and teaching } \\
\hline Tradition & \\
\hline
\end{tabular}

Usually these societal references are rather abstract, but they communicate a self-image of the universities to the outside world in which science is not a means in itself, but has to fulfil a social mission. Consequently, they convey an impression that publicly-funded universities are serving society.

About two thirds of all universities mention co-operation with non-scientific partners in their mission statements. Most of these co-operations are research projects or partnerships with companies in the industrial sector. $63 \%$ of the universities also describe knowledge and/or technology transfer in a general, unspecified way. About half of the analyzed mission statements also make reference to personal transfer, mostly in the form of alumni networks and relations. Only about a third of the universities highlight their commitment to commercialization activities, such as spinning out companies or licensing property rights.

Table 4 Descriptive statistics of the analyzed university mission statements

\begin{tabular}{lllllll}
\hline & Total & Mean & Median & Standard dev. & Highest & Lowest \\
\hline Words & 60,116 & 824 & 637 & 695.3 & 4029 & 104 \\
Codes (total) & 1989 & 27.2 & 23 & 18.9 & 120 & 4 \\
Codes (third mission) & 383 & 5.25 & 4 & 5.38 & 32 & 0 \\
\hline
\end{tabular}


Compared to knowledge and technology transfer, further education plays a less important role in the self-description of universities. Although $37 \%$ of universities mention further education in their mission statements, they usually only refer to it in an abstract and general way, without mentioning particular offers, examples and structures or detailed information. Less than $20 \%$ of the mission statements describe concrete advanced study programs and only four universities mention co-operation activities with other actors of further education as well as informal further education activities such as guest studies. Consequently, despite its high social significance, further education obviously has a much lower profiling potential than knowledge and technology transfer.

In the case of social engagement this evidence becomes even more obvious. Widening participation and extended access to higher education is addressed in only 13 of 73 mission statements, aspects of open science only in 12, even though all university laws demand this in detail (Berghäuser 2017). The other subcategories such as community outreach, community service, service learning or civic engagement are mentioned in less than $10 \%$ of the mission statements. Topics like citizen science and social entrepreneurship are not addressed at all. Overall, social engagement appears to be a niche topic in the external presentation of universities rather than a task which all universities feel committed to address. Figure 1 presents the share of codes relating to third mission activities in the mission statements of 73 German universities.

In a further step, we analyzed the role of third mission in general and compared its core components - knowledge and technology transfer, further education and social engagement - to other topics that were found in the mission statements. Assuming that mission statements are used as an instrument of self-marketing primarily in order to address the needs and interests of their institutional environment, the diversity of topics reflect the numerous and diverse demands and challenges that universities face. Figure 2 summarizes the share of the topics we identified in the university mission statements.

The most frequently mentioned topic in the mission statements is inter- or transdisciplinary research. Nine of ten mission statements mention this aspect in the description of their academic profile. It seems that cross-disciplinary research cooperation is seen as highly important within universities. The reasons for this are not totally clear. One factor might be the intense discussion around "mode 2-knowledge" (Gibbons et al. 1994; Nowotny et al. 2001) in Germany and the need for such cooperation when addressing real-world-problems. Many universities have created interdisciplinary research centres during the last few years, such as the Centre for the Environment or the Centre for Social Innovation at the University of Heidelberg. Besides a general societal reference, international networks is another topic most universities allude to. A majority of universities also describe themselves as modern, innovative and service-oriented.

At the same time, universities also adhere to an organizational tradition or make historical references. By doing this, universities not only describe positive highlights and great achievements in their history. Some universities also address negative historical aspects like their involvement in Nazi Germany or in Socialist East Germany to demonstrate their historical awareness and civil-society responsibility. Excellent and high quality research and/or teaching is named in more than three quarters of all mission statements. The majority of the mission statements also make references to the region where the universities are located and describe their commitment to the promotion of young academics, ethnic diversity, gender equality, family friendliness and sustainability. 


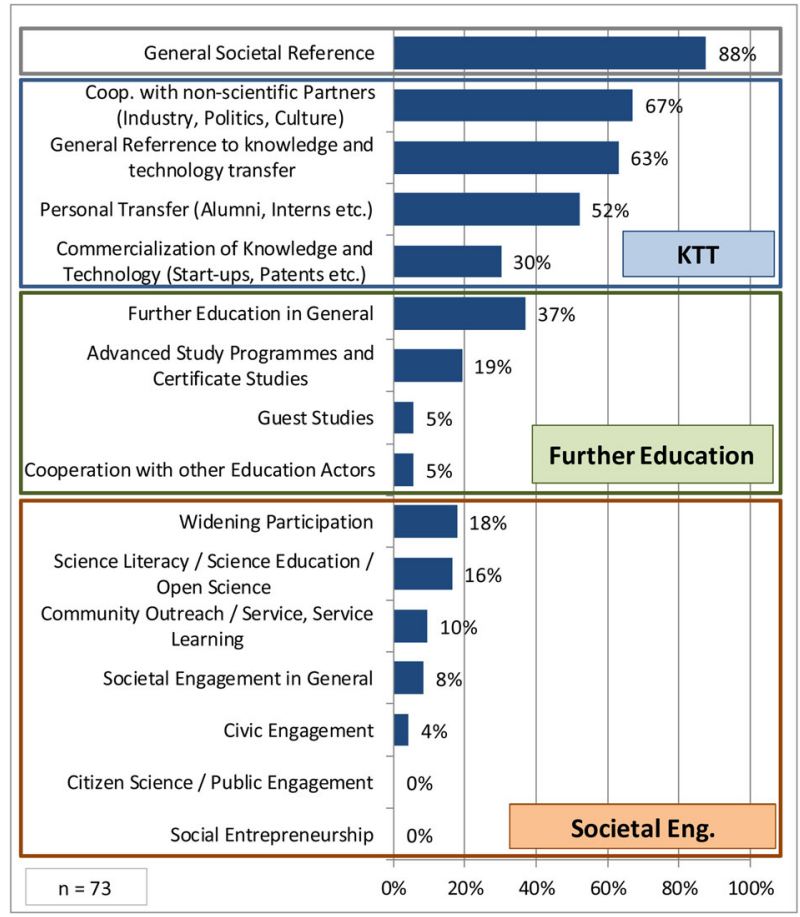

Fig. 1 Third mission in university mission statements

Knowledge and technology transfer is not only mentioned particularly frequently in comparison to other categories of the third mission, but also in comparison to most other topics that we identified in the mission statements. $84 \%$ of the universities address at least one aspect of knowledge and technology transfer - research cooperation, commercialization activities or personal transfer. Thus, knowledge and technology transfer represents a central part of the self-description of universities. Further education is mentioned in almost half of the mission statements, aspects of social engagement only in about one third of all profiles. In addition to that, almost all universities refer to society or describe their social impact, expressing their responsibility with regard to social challenges.

Overall, the third mission is firmly anchored in the self-description of German universities. However, the third mission is mainly expressed in thematic terms of knowledge and technology transfer, while aspects of further education and especially societal engagement are much less prominent.

\section{Conclusion}

Universities' third mission has become highly important in the political and societal discourse within the last few years. An important question is how universities react to this increased demand for transfer, further education and social engagement. Basic neo-institutional theory (Meyer and Rowan 1977; DiMaggio and Powell 1983) suggests isomorphic behavior among 


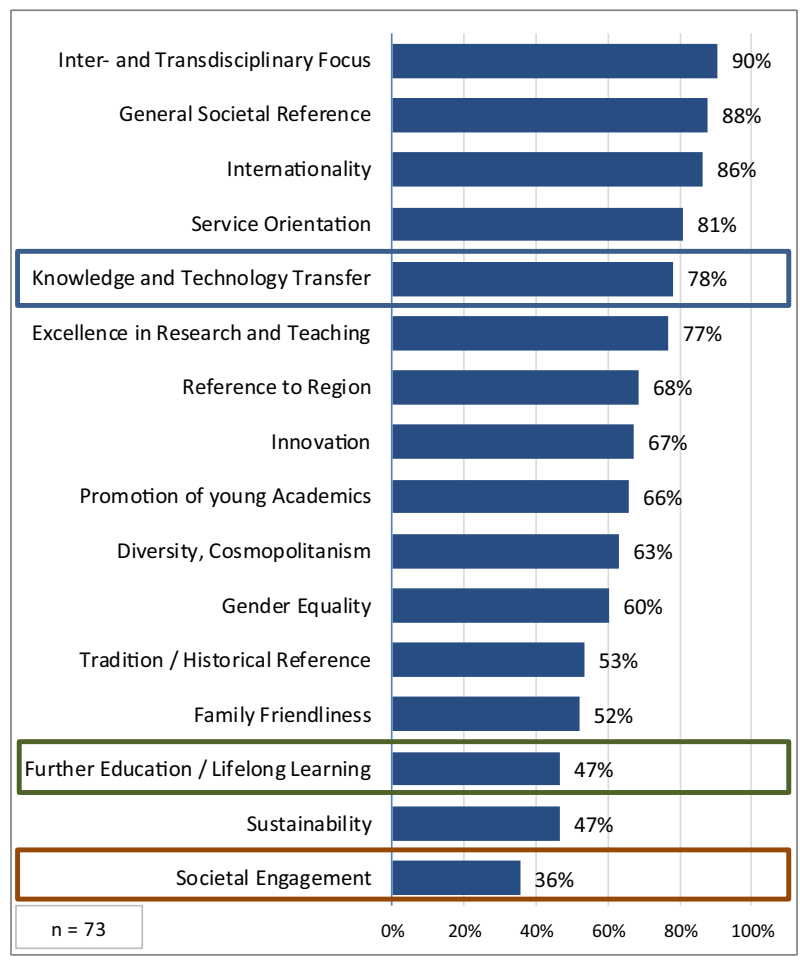

Fig. 2 The role of third mission in university mission statements

universities. This article empirically tests a specific aspect of this by confronting demands of higher education laws regarding third mission with universities' self-descriptions in their mission statements for Germany.

As the qualitative content analysis of the 73 university mission statements shows, third mission plays a central role in the external communication of universities in Germany. There is hardly any university whose mission statement does not address the third mission in some way, and almost all universities connect their functions and activities to societal challenges. In line with the existing German literature (Pasternack et al. 2015; Henke et al. 2016a, b; Roessler et al. 2015; Hachmeister et al. 2016), three dimensions of third mission activities were identified: knowledge and technology transfer, further education/lifelong learning, and societal engagement. Almost $90 \%$ of universities mention at least one aspect of knowledge and technology transfer in their mission statements, whereby (research) co-operation with nonscientific partners is most frequently mentioned. All in all, the high reference of aspects of knowledge and technology transfer is striking and illustrates the central role of this topical field in the self-description and external presentation of German universities.

Compared to knowledge and technology transfer, further education plays a less important role in mission statements. Only about $20 \%$ of the universities mention specific further education programs such as degree or certificate studies. Guest studies or cooperation with other providers of further education are hardly mentioned at all. Consequently, despite its great social significance and definition as a political demand, the topic of further education obviously has a much lower profile potential than knowledge and technology transfer in the 
external presentation of universities. This becomes even more obvious in the case of societal engagement. Just 13 of 73 mission statements mention widening participation and access to higher education. Only 12 describe their open access strategies or activities. The other subcategories regarding social engagement are hardly mentioned at all. Overall, societal engagement appears to be a small niche topic rather than a sincere commitment in the external presentation of German universities.

By comparing these results with legal requirements, as put down in the 16 higher education laws of the German states (Länder), it becomes obvious that isomorphism can only be observed to some extent. Within the laws, knowledge and technology transfer as well as further education activities are mentioned in detail, as is widening participation as one aspect of social engagement. Isomorphic tendencies are clearly visible with regard to knowledge and technology transfer. Nearly all universities refer to knowledge and technology transfer in their mission statements, as do the laws. However, although further education and widening participation are also concrete tasks in the 16 higher education laws to which universities are expected to devote themselves, references to these, and especially to all forms of social engagement, are much less frequent.

According to basic neo-institutionalist assumptions, one would expect universities to emphasize their impact on society much more intensively and comprehensively, at least in the field of further education. However, as the summarized empirical results in Fig. 3 show we found only few references concerning further education in the mission statements in spite of strong emphasize in the higher education laws.

This seems to support an interpretation of universities as "institutional entrepreneurs" (Garud et al. 2007; Thornton et al. 2013). As organizations they are to some extent able to "choose" from a broad array of demands and tasks, often even conflicting claims, attributed to them by policy and society. The various topics identified in the mission statements indicate universities' reaction to external expectations of increased engagement in more than just teaching and research. Universities are not only required to be excellent in teaching and research. Politics and society also want both to be inter- and transdisciplinary, as well as impact-oriented. Over and above the third mission, universities are also requested to engage in international networks and have close connections to the region and their historical tradition. As modern organizations, universities also feel obligated to be innovative and family-friendly, to embrace diversity, sustainability and gender equality and to promote young academics.

This illustrates the large amount of tasks, challenges and global trends universities in Germany (and elsewhere) are expected to address. As a consequence, setting priorities, also in profiling, as well as strategies of "compartmentalization and blending" (Canhilal et al. 2016), are inevitable in regard to the various demands placed on them. Of all aspects of the third mission, co-operation with industry partners in particular seems most important for the medium and long-term planning of universities. The fact that universities hardly mention activities related to social engagement or further education, even though these topics are clearly defined as university tasks, shows that, at least in this regard, legitimacy is not an important trigger for action.

These results contradict neo-institutionalist assumptions according to which organizations reflect institutionalized demands into their formal structure. Instead, universities seem to formulate and develop their own strategy according to their individual organizational interests, and too often this seems to result in an anticipatory obedience to claims of the economy.

However, the findings ask for some further research. First, it is difficult to assess on the basis of mission statements alone to what extent the focus on knowledge and technology 


\begin{tabular}{|c|c|c|c|c|c|c|c|}
\hline & & \multicolumn{6}{|c|}{ Higher education laws } \\
\hline & & \multicolumn{2}{|c|}{$\begin{array}{l}\text { Knowledge and } \\
\text { technology transfer }\end{array}$} & \multicolumn{2}{|c|}{$\begin{array}{c}\text { Further } \\
\text { education }\end{array}$} & \multicolumn{2}{|c|}{$\begin{array}{c}\text { Social } \\
\text { engagement }\end{array}$} \\
\hline & & strong & weak & strong & weak & strong & weak \\
\hline \multirow{2}{*}{$\begin{array}{l}\text { University Mission } \\
\text { Statements }\end{array}$} & strong & $\star$ & & & & & \\
\hline & weak & & & * & & & * \\
\hline
\end{tabular}

Fig. 3 Assessing expected isomorphism (comparing higher education laws and mission statements). Dark gray = Expected outcome; * empirical observation

transfer is following from the marketization of higher education. The results of our analysis suggest that in Germany one finds a limited understanding of the public mission of universities along neo-liberal higher education policies with a strong focus on economy-related aspects of third mission. However, as neo-institutional theory also claims, there might be a decoupling of mission statements and activities within the universities. It is therefore necessary to analyze not only the context (laws) and the formal answer (mission statements of higher education institutions), but also the engagement of the university-members (informal behavior) with regard to knowledge and technology transfer, further education and social engagement. It has to be assessed in further studies to what extent the focus of mission statements on economic aspects is leading to corresponding action at the micro-level.

Second, the legitimizing context does not only consist of higher education laws, but is shaped by a variety of influences, such as pressures from the economy (though their share of financing higher education is quite small in Germany, around 6\% in 2015), funding schemes (e.g. funding by the European Union with a strong focus on company-involvement), reputation patterns and discourses in civil society. Further research is needed to compare the role of these different influences and how they are taken up by universities. This would especially benefit from an international comparison to see to what extent the findings reflect a "German Sonderweg", as, for example, social engagement of students as part of the curriculum seems to be much more prominent in the US and some other countries.

Third, neo-institutional theory is aware of the inertia of institutions. Therefore, the drive for legitimacy may push universities in a certain direction, but older traditions clearly also play a role. For example, the German higher education sector is traditionally weak in the field of further education, although we find a growing importance of this sector recently (Wolter 2011). It would therefore be interesting to look at developments over time to identify trends.

To conclude, the empirical analysis showed that universities' mission statements in Germany are dominated by economy-related issues, although university laws ask for a much broader consideration of third mission activities. With regard to theoretical considerations, this suggests that neo-institutional isomorphism should not be overestimated, as even in the "coercive" field of legal contexts not all demanded aspects of third mission are taken up. Instead, newer interpretations of universities as institutional entrepreneurs with a certain freedom to choose their way between different claims may be more appropriate. With regard to practical considerations the presented results pose the question to what extent knowledge and technology transfer activities dominate or even compromise more engaged and 
empowering activities that are still a strong part of the informal action structures of German universities.

Open Access This article is distributed under the terms of the Creative Commons Attribution 4.0 International License (http://creativecommons.org/licenses/by/4.0/), which permits unrestricted use, distribution, and reproduction in any medium, provided you give appropriate credit to the original author(s) and the source, provide a link to the Creative Commons license, and indicate if changes were made.

\section{References}

Abreu, M., \& Grinevich, V. (2013). The nature of academic entrepreneurship in the UK: Widening the focus on entrepreneurial activities. In Research Policy (Vol. 42, pp. 408-422).

Bercovitz, J., \& Feldman, M. (2006). Entrepreneurial universities and technology transfer: A conceptual framework for understanding knowledge-based economic development. Journal of Technology Transfer, $31,175-188$.

Berghäuser, H. (2017): Die Dritte Mission in der Hochschulgovernance. Eine Analyse der Landeshochschulgesetze. In: Hochschulmanagement - Zeitschrift für die Leitung, Entwicklung und Selbstverwaltung von Hochschulen und Wissenschaftseinrichtungen (2+3), pp. 35-43.

Berthold, C.; Meyer-Guckel, V.; Rohe, W. (2011): Mission Gesellschaft. Engagement und Selbstverständnis der Hochschulen. Ziele, Konzepte, internationale Praxis. Edition Stifterverband.

Blair-Loy, M.; Wharton, A. S.; Goodstein, Jerry (2011): Exploring the relationship between Mission statements and work-life practices in organizations. In: Organization Studies 32 (3), pp. 427-450.

Boxenbaum, E., \& Jonsson, S. (2008). Isomorphism, diffusion and decoupling. In R. Greenwood, C. Oliver, K. Sahlin, \& R. Suddaby (Eds.), The SAGE handbook of organizational institution (pp. 78-98). Thousand Oaks: Sage Publications Inc..

Bozeman, B. (2000). Technology transfer and public policy: A review of research and theory. Research Policy, $29,627-655$.

Brown, R. (2016): Mission impossible? Entrepreneurial universities and peripheral regional innovation systems. In: Industry and Innovation 23 (2), pp. 1-17.

Statistisches Bundesamt (2018): Studierende an Hochschulen Wintersemester 2017/2018 - Vorbericht. Wiesbaden.

Canhilal, S. K., Lepori, B., \& Seeber, M. (2016). Towards a comparative institutionalism: Forms, dynamics and logics across the organizational fields of health care and higher education. Research in the Sociology of Organizations, 45, 169-194.

Davies, S. W.; Glaister, K. W. (1996): Spurs to higher things? Mission statements of UK universities. In: Higher Education Quarterly 50 (4), pp. 261-294.

Delucchi, M. (2000): "Liberal arts" colleges and the myth of uniqueness. In: Sociological Inquiry 70 (2), pp. 157-171.

Desmidt, S.; Prinzie, A.; Decramer, A. (2011): Looking for the value of mission statements: A meta-analysis of 20 years of research. In: Management Decision 49 (3), pp. 468-483.

DiMaggio, P. J., \& Powell, W. W. (1983). The Iron cage revisited: Institutional isomorphism and collective relationality in organizational fields. In American Journal of Sociology (Vol. 48, pp. 147-160).

Etzkowitz, H., \& Leydesdorff, L. (2000). The dynamics of innovation: From National Systems and "mode 2" to a triple Helix of university-industry-government relations. In Resesarch Policy (Vol. 29, pp. 109-123).

Garud, R.; Hardy, C.; Maguire, S. (2007): Institutional entrepreneurship as embedded agency. An Introduction to the Special Issue, in: Organizational Studies 28 (7), S.957-969.

Gibbons, M., Limoges, C., Nowotny, H., Schwartzman, S., Scott, P., \& Trow, M. (1994). The new production of knowledge. London: Sage Publications Ltd..

Glaser, A., O'Shea, N., \& Chastenet de Gery, C. (2014). Measuring third mission activities of higher education institutes. Belfast: Constructing an evaluation framework. Paper presented at British Academy of Management Conference.

Gläser-Zikuda, M. (2008): Qualitative Inhaltsanalyse in der Lernstrategie- und Lernemotionsforschung. In: P. Mayring and M. Gläser-Zikuda (Hg.): Die Praxis der Qualitativen Inhaltsanalyse. 2. Auflage. Weinheim: Beltz Verlag, pp. 63-83.

Göransson, B.; Maharajh, R.; Schmoch, U (2009): New activities of universities in transfer and extension: Multiple requirements and manifold solutions. In: Science and Public Policy 36 (2), pp. 157-164. 
Hachmeister, C.-D.; Henke, J.; Roessler, I.; Schmid, S. (2016): Die Vermessung der Third Mission. Wege zu einer erweiterten Darstellung von Lehre und Forschung. In: die Hochschule 1/2016, pp. 7-13.

Hall, P., \& Soskice, D. (2001). Varieties of capitalism. The institutional foundations of comparative advantage. Oxford: Oxford University Press.

Hanft, A. (2000): Leitbilder an Hochschulen - Symbolisches oder Strategisches Management? In: Hanft, A. (Hrsg.): Hochschulen managen? Neuwied, pp. 121-133.

Hanft, A., \& Brinkmann, K. (2013). Offene Hochschulen. Die Neuausrichtung der Hochschulen auf Lebenslanges Lernen. Münster: Waxmann Verlag GmbH.

Henke, J.; Pasternack, P.; Schmid, C. J. (2016a): Third Mission bilanzieren. Die dritte Aufgabe der Hochschulen und ihre öffentliche Kommunikation. HoF-Handreichungen 8. Beiheft zu "die Hochschule".

Henke, J.; Pasternack, P.; Schmid, S. (2016b): Third Mission von Hochschulen. Eine Definition. In: Das Hochschulwesen 64 (1/2), pp. 16-22.

Hoelscher, M. (2016). Spielarten des akademischen Kapitalismus. Hochschulsysteme im internationalen Vergleich. Wiesbaden: Springer VS.

Hüther, O. (2010). Von der Kollegialität zur Hierarchie? Eine Analyse des New Managerialism in den Landeshochschulgesetzen. Wiesbaden: VS Verlag für Sozialwissenschaften.

Hüther, O.; Krücken, G. (2018): Higher education in Germany - Recent developments in international perspective. Cham: Springer international publishing AG (higher education dynamics, 49).

James, H., \& Huisman, J. (2009). Mission statements in Wales: The impact of markets and policy on congruence between institutions. Journal of Higher Education Policy and Management, 31(1), 23-35.

Jungblut, J., \& Jungblut, M. (2017). All different? All equal? Differentiation of universities' mission statements and excellence initiatives in Germany. Science and Public Policy, 44(4), 535-545.

Kehm, B. M.; Pasternack, P. (Hg.) (2001): Hochschulentwicklung als Komplexitätsproblem. Fallstudien des Wandels. Weinheim and Basel: Beltz.

Kersting, T. (2013). Wissens- und Technologietransfer durch Hochschulen aus einer marktorientierten Perspektive. Springer Fachmedien: Ansatzpunkte zur Gestaltung erfolgreicher Transferprozesse an Universitäten und Fachhochschulen. Wiesbaden.

Koschatzky, K. (2002). Hochschulen im regionalen Gründungskontext. In K. Koschatzky \& M. Kulicke (Eds.), Wissenschaft und Wirtschaft im regionalen Gründungskontext (pp. 21-36). Stuttgart: Fraunhofer IRB Verlag.

Kosmützky, A. (2010). Von der organisierten Institution zur institutionalisierten Organisation? Eine Untersuchung der (Hochschul-)Leitbilder von Universitäten. Bielefeld: Universität Bielefeld.

Kosmützky, A.; Krücken, G. (2015): Sameness and difference: Analyzing institutional and organizational specificities of universities through Mission statements. In: International Studies of Management \& Organization 45 (2), pp. 137-149.

Krücken, G. (2003). Learning the 'New, new Thing': On the role of path dependency in university structures. Higher Education, 43, 315-339.

Lissmann, U. (1997). Inhaltsanalyse von Texten. Landau: Verlag Empirische Pädagogik.

Loi, M., \& Di Guardo, M. C. (2015). The third mission of universities: An investigation of the espoused values. Science and Public Policy, 42, 855-870.

Mackay, L., Scott, P., \& Smith, D. (1995). Restructured and differentiated? Institutional responses to the changing environment of UK higher education. Higher Education Management, 7(2), 193-203.

Markman, G., et al. (2005). Entrepreneurship and university-based technology transfer. In Journal of Business Venturing (Vol. 20, pp. 241-263).

Mayring, P. (2015). Qualitative Inhaltsanalyse. Grundlagen und Techniken. 12. aktualisierte und (überarbeitete Auflage ed.). Weinheim: Beltz Verlag.

Meier, F. (2009). Die Universität als Akteur. Zum institutionellen Wandel der Hochschulorganisation. Wiesbaden: VS Verlag für Sozialwissenschaften.

Meyer, H.-D. (2002). Introduction: From "loose coupling" to "tight management"? Making sense of the changing landscape in management and organization theory. Journal of Educational Administration, 40(6), 515-520.

Meyer, J. W.; Rowan, B. (1977): Institutionalized organizations: Formal structure as myth and ceremony. In: American Journal of Sociology 83 (2), S. 340-362.

Moore, B., Hughes, A., \& Ulrichsen, T. (2009). The evolution of the infrastructure of the knowledge exchange system. London and Cambridge: A Report to HEFCE by PACEC and the Centre for Business Research. PACEC and the University of Cambridge.

Münch, R. (2014). Academic capitalism. Universities in the global struggle for excellence. New York: Routledge.

Musselin, C. (2007): Are universities specific Organisations? In: G. Krücken, A. Kosmützky; M. Torka (Hg.): Towards a multiversity? Universities between global trends and National Traditions. Bielefeld: Transcript Verlag, pp. 63-86.

Nowotny, H., Scott, P., \& Gibbons, M. (2001). Re-thinking science: Knowledge and the public in an age of uncertainty. Oxford: Polity Press. 
Orton, J. D.; Weick, K. E. (1990): Loosely coupled systems: A reconceptualization. In: The Academy of Management Review 15 (2), pp. 203-223.

Pasternack, P.; Schneider, S.; Zierold, S. (2015): Programmatik und Aktivitäten. Die hochschulischen Leistungsstrukturen in regionalen Kontexten. In: M. Fritsch, P. Pasternack; M. Titze (Hg.): Schrumpfende Regionen - dynamische Hochschulen. Hochschulstrategien im demografischen Wandel. Wiesbaden: Springer Fachmedien, pp. 89-118.

Perkman, M., \& Walsh, K. (2008). Engaging the scholar: Three forms of academic consulting and their impact on universities and industry. In Research Policy (Vol. 37, pp. 1884-1891).

Phillips, D.; Ochs, K. (2003): Processes of policy borrowing in education: Some explanatory and analytical devices. In: Comparative Education 39(4), pp. 451-461.

Powell, W. W.; Bromley, P. (2013): New institutionalism in the analysis of complex organizations. Prepared for the international encyclopedia of social and behavioral sciences, 2nd edition.

Powell, W. W., \& Snellman, K. (2004). The knowledge economy. In Annual Review of Sociology (Vol. 30, pp. 199-220).

Ramirez, F. O., \& Christensen, T. (2013). The formalization of the university: Rules, roots, and routes. In Higher Education (Vol. 65, pp. 695-708).

Roessler, I., Duong, S., \& Hachmeister, C.-D. (2015). Welche Missionen haben Hochschulen? Third Mission als Leistung der Fachhochschulen für die und mit der Gesellschaft. Gütersloh: http://www.che. de/downloads/CHE_AP_182_Third_Mission_an_Fachhochschulen.pdf. Accessed 15 Sept 2018.

Sanchez, R., \& Heene, A. (2004). The new strategic management: Organization, competition, and competence. New York: Wiley.

Schaeper, H., Schramm, M., Weiland, M., \& Wolter, A. (2006). International vergleichende Studie zur Teilnahme an Hochschulweiterbildung. Abschlussbericht. Hannover: Hochschulinformations-System GmbH.

Schmoch, U., Licht, G., \& Reinhard, M. (2000). Wissens- und Technologietransfer in Deutschland. Stuttgart: Fraunhofer IRB Verlag.

Schuetze, H. G. (2005). Modelle und Begründung lebenslangen Lernen und die Rolle der Hochschulen Internationale perspektiven. In G. Wiesner \& A. Wolter (Eds.), Die lernende Gesellschaft (pp. 225-244). Juventa: Weinheim.

Selznick, P. (1948). Foundations to the theory of organization. In American Sociological Review (Vol. 13, pp. 2535).

Selznick, P. (1957). Leadership in administration. Berkeley: University of California Press.

Shattock, M. (2005): European universities for entrepreneurship: Their role in the Europe of knowledge. The theoretical context. In: Higher Education Management and Policy 17 (3), pp. 13-25.

Stearns, J.M.; Borna, S. (1998): Mission statements in business higher education: Issues and evidence. In: Higher Education Management 10 (1), pp. 89-104.

Thompson, J. D. (1967). Organizations in action. New York: McGraw-Hill.

Thornton, P. H., Ocasio, W., \& Lounsbury, M. (2013). The institutional logics perspective. A new approach to culture, structure, and process. Oxford: Oxford University press.

Trow, M. (1972): The expansion and transformation of higher education. In: International Review of Education 18(1), pp. 61-84.

Weber, L., \& Duderstads, J. (Eds.). (2006). Universities and business: Partnering for the knowledge society. Economica: London et al.

Weick, K.E. (1982): Administering education in loosely coupled schools. In: The Phi Delta Kappan 63 (10), pp. 673-676.

Wolter, A. (2011): Die Entwicklung wissenschaftlicher Weiterbildung in Deutschland: Von der postgradualen Weiterbildung zum lebenslangen Lernen. In. Beiträge zur Hochschulforschung 33(4), pp. 8-35.

Zomer, A.; Benneworth, P. (2011): The rise of the University's third Mission. In: J. Enders; H. de Boer; D.F. Westerheijden (Hg.): Reform of higher education in Europe. Rotterdam: Sense Publishers, pp. 81-101.

Publisher's note Springer Nature remains neutral with regard to jurisdictional claims in published maps and institutional affiliations. 